\title{
ISLAMIC BANKING EXISTENCE AND DOMESTIC CREDIT: STUDY AT SEVEN COUNTRIES
}

\author{
Hamdan Yuafi ${ }^{1}$, Anton Bawono ${ }^{2}$
}

\begin{abstract}
Islamic Banking Existence and Domestic Credit: Study at Seven Countries. This paper empirically investigates the determinants of domestic credit across a wide range of 7 countries; these are United Kingdom, Malaysia, Egypt, Kuwait, Qatar, Bahrain and Indonesia. We use dynamic panel estimation to examine effects of exchange rate, inflation, lending interest rate, banking crisis and existence of wholesale Islamic banking on domestic credit. We obtain several notable empirical results. First, the lending interest rate, banking crisis negatively and insignificantly contribute to domestic credit. The existence of Islamic bank has positive and insignificant contribution to domestic credit, while exchange rate positively and significantly contributes to domestic credit. Inflation negatively and significantly contributes to domestic credit. Second, banking crisis and existence of wholesale Islamic banking show insignificant effect on domestic credit. Third, we find that today's domestic credit is depended on domestic credit in the previous year.
\end{abstract}

Keywords: Islamic banking, market risk, banking crisis, domestic credit

\begin{abstract}
Abstrak. Keberadaan Bank Syariab dan Kredit Domestik: Studi di Tujub Negara. Penelitian ini secara empiris meneliti faktor-faktor penentu kredit domestik di 7 negara; Inggris, Malaysia, Mesir, Kuwait, Qatar, Bahrain dan Indonesia. Kami menggunakan estimasi data panel untuk mengetahui hubungan dari nilai tukar, inflasi, suku bunga pinjaman, krisis perbankan dan eksistensi perbankan syariah terhadap domestik kredit. Dari penelitian ini diperoleh 3 hasil empiris. Pertama, suku bunga pinjaman, krisis perbankan berpengaruh negatif dan tidak signifikan terhadap kredit domestik. Keberadaan bank syariah memiliki kontribusi positif dan signifikan terhadap domestik kredit, sementara nilai tukar memiliki hubungan positif dan signifikan terhadap kredit domestik. Inflasi berpengaruh negatif dan signifikan terhadap kredit domestik. Kedua, krisis perbankan dan adanya perbankan syariah berpengaruh signifikan pada kredit domestik. Ketiga, kami menemukan bahwa kredit dalam negeri tahun ini sangat bergantung pada kredit domestik pada tahun sebelumnya.
\end{abstract}

Kata kunci: bank syariah, risiko pasar, krisis perbankan, kredit domestik 


\section{Introduction}

What are the main factors that determine domestic credit levels in developing economies? Answering this question is a noteworthy issue, particularly given that most countries with Islamic Economics (henceforth CIE's) had not experienced severe boom credit in the last decade. Indeed, the effects of domestic credit on economic activity and financial stability are well documented, along with the experiences of the banking and financial crises in many places, but it didn't have big impact on country with Islamic Banking. For example, the research by Abduh, et.al (2011), in this research we knew that crisis has a positive impact on Islamic Banking. Nevertheless, some recent studies have shown that sustainable domestic credit growth in a developing economy would significantly improve welfare (Obstfeld, 2012). The aim of this paper is to empirically investigate domestic credit dterminants across awide range of 7 CIE's over the period 1980-2014 within dynamic panel data estimation framework.

In case of domestic credit system, the term "domestic credit" refers to lending or credit that a country or territory's central bank makes available to borrowers within the same territory (Pandit, 2016). This may include commercial banks which can be conventional bank and Islamic bank. Islamic bank has same function as conventional bank, collect fund from surplus people in the form of deposit and provide it to the deficit people in the form of financing facility. Unlike traditional banks, Islamic banks' funding comes from deposit and profit-sharing investment accounts with a return decided by the bank's profit. Talking about Islamic bank facilities, there are nine CIE in the world that have biggest operation of Islamic finance. The most significant players are Gulf Cooperation Council (GCC) countries, which account for the vast majority of assets. That said, the model is also making headway in countries such as Malaysia, Indonesia, Turkey and Pakistan.

According to Ernst \& Young, total Islamic finance assets of commercial banks rose 17\% between 2009 and 2013, hitting $\$ 778$ billion. Of that, Gulf Cooperation Council (GCC) countries account for around $\$ 517$ billion, ASEAN countries for $\$ 160$ billion and South Asia for $\$ 23$ billion; with the rest of the world (especially Turkey) making up the remaining $\$ 78$ billion. Although the pace of growth has been impressive, the share of Islamic financial assets remains only a small fraction of global financial assets (less than 1\%). However, its double-digit growth is comfortably outpacing that of conventional banking. Unfortunately, while the industry is gaining ground, its profitability has so far lagged behind that of comparable conventional banking institutions. Average return on equity in leading Islamic finance banks between 2009 and 2013 was $11.9 \%$, against a 14.5\% return from traditional banks. 
The IMF warns of the need to ensure an appropriate regulatory regime surrounding these nascent institutions due to the risks related to the business model (WEF, 2016). These include managing market risk and dealing with the complexity of transactions and corporate structure that is required in facing market risk. That is why we choose market risk variables risk as predictors, such as benchmark rate or interest rate, exchange rate and inflation rate. And based on the data that is shown above the writer took seven countries as research object. Islamic bank must aware not only on market risk but also on nature risk such as economic crisis. The New Palgrave Dictionary of Banking Crises defines that there are two distinct phenomena associated with banking system distress: exogenous shocks that produce insolvency and depositor withdrawals during 'panics'. These two contributors to distress often do not coincide (Jones, 2016). Moreover, serious financial crises, most notably the Great Depression and the financial crisis of 2007-2008, lead to panics, loss of business and consumer confidence, deleveraging, severe and prolonged recessions or depressions, long-lasting periods of high unemployment, and, ultimately and most ominously, unbearable pressure on families and on the fabric of society and social cohesion (Askari, 2015).

As will be discussed in Section 2 below, there is a growing empirical literature examining the determinants of domestic credit, but the best decisive factors remain unclear. Moreover, the determinants of domestic credit levels appear to be complicated. The ability to borrow from abroad allows a country to borrow at lower interest rates and with less pressure on the nominal exchange rate and thus on inflation than if the country is economically and financially closed (Obstfeld, 2012). Thus, domestic credit may not only be driven by market risk factors, such as benchmark rate or interest rate, exchange rate and inflation rate, but also by natural factors, such as domestic crisis, and domestic market conditions.

Does the banking crisis have an effect on Islamic banking? As Askari (2015) said that the frequency of these crises increased in the last decades of the twentieth century and culminated in the devastating global crisis of 20072008. As unfortunate as these crises have been, they have held lessons for Islamic finance, which still is in its nascent stage of development, especially since Islamic finance is now operating in an institutional framework that is basically that of the conventional debt driven system. This research wants to contribute to the existing literature in several ways. To the best of our knowledge, this paper is the first to examine the effects on domestic credit expansion in CIE's of both macroeconomic demand and financial condition factors. Second, this is the first study to analyze the impact of existence of Islamic banking on domestic credit in CIE's. 


\section{Literature Review}

Is an Islamic bank more resilient to crisis? The most well-known study is conducted by IMF (2011). A recent IMF study compares the performance of Islamic banks and conventional banks during the recent financial crisis, and finds that Islamic banks, on average, showed stronger resilience during the global financial crisis. But the study also finds that Islamic banks faced larger losses than their conventional peers when the crisis hit the real economy. To control in varying conditions across financial systems, the IMF looks at the actual performance of Islamic banks and conventional banks in countries where both have significant market shares (see Figure 1). It uses bank-level data covering 2007-10 for about 120 Islamic banks and conventional banks in eight countries-Bahrain, Jordan, Kuwait, Malaysia, Qatar, Saudi Arabia, Turkey, and the United Arab Emirates. These countries host most of the world's Islamic banks (more than 80 percent of the industry, excluding Iran) but also have large conventional banking sectors. The key variables used to assess the impact are the changes in profitability, bank lending, bank assets, and external bank ratings.

Figure 1. Performance of Islamic banks and conventional banks 2005-2007

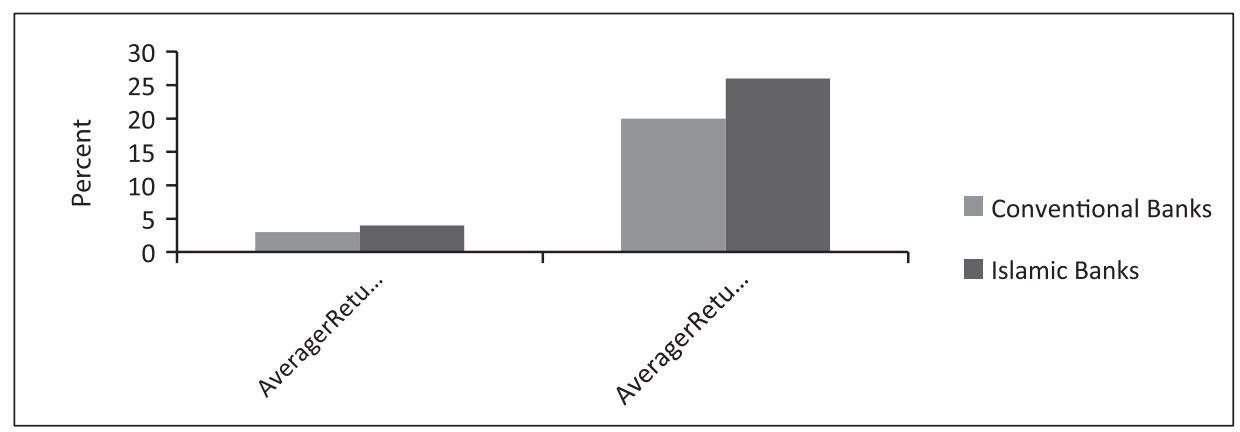

Source: IMF, 2014

The analysis suggests that Islamic banks fared differently from conventional banks during the global financial crisis. Factors related to the Islamic banking business model helped contain the adverse impact on their profitability in 2008 (see Figure 2). In particular, smaller investment portfolios, lower leverage, and adherence to Sharia principles which precluded Islamic banks from financing or investing in the kind of instruments that have adversely affected their conventional competitorshelped contain the impact of the crisis on Islamic banks in that year. 
Figure 2. Change in profit, credit, and assets from 2007 to 2008

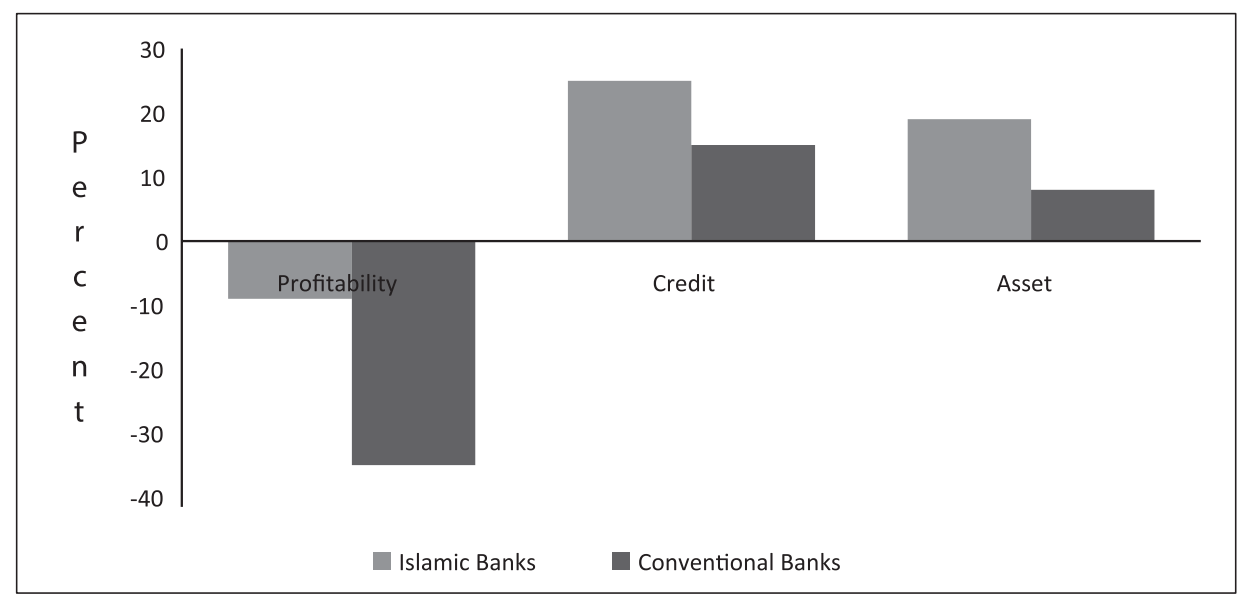

Source: IMF, 2014

Despite the higher profitability of Islamic banks during the pre-global crisis period (2005-2007), their average profitability for 2008-2009 was similar to that of conventional banks, indicating better cumulative profitability and suggesting that higher pre-crisis profitability was not driven by a strategy of greater risk taking. The analysis also shows that large Islamic banks fared better than small ones, perhaps as a result of better diversification, economies of scale, and stronger reputation. Development of the industry might therefore be achieved, the paper suggests, through establishing large, well-managed Islamic banks that can compete with existing banks. Based on this result study we want to re-examine about the impact of banking crisis on domestic credit to private sector by bank in most of the world's Islamic banks plus United Kingdom as most developing country in Europe in field of Islamic finance development.

World Bank (2016) defined that a domestic credit to private sector by banksrefers to financial resources provided to the private sector by other all financial institution, especially banking institution. This concept is widely used in financial market throughout the world. This concept also used to monitor the behaviour of an economic development in many countries. There are many factors that affect domestic credit, in this research we used 6 (six) variables such as exchange rate, inflation, lending interest rate, which are categorized as market risk determinants. The other two variables are dummy variable which are banking crisis and existence of Islamic banking, these two variable are brad new variables that is used in determining domestic credit. The last variable is an autoregressive variable of domestic credit to private sector by banks. 
At least the writers had found twelve researches that describe the relation between those six variables and domestic credit, the arrangement of the literature review below is presented as each relation of one independent variable toward domestic credit, for example the first until the third are a discussion about the relation between exchange rate and domestic credit and so on. First, Ezeji (2014) examines the impact of macroeconomic variables on domestic credit using Nigeria data over a period 1980-2012 in an attempt to contribute to the growth of banking sector. More specifically, the study seeks to determine whether interest rate, inflation, money supply, exchange rate have a long run relationship on domestic credits in the banking sector in Nigeria. The study confirmed that the exchange rate, interest rate, inflation indicators used in the study has some influence on domestic credit.

Second, Magud et al. (2011) analyze the impact of exchange rate flexibility on credit markets during periods of large capital inflows. They show that credit grows more rapidly and its composition tilts to foreign currency in economies. Third, Aghion et al. (2009) empirical evidence that real exchange rate volatility can have a significant impact on long-term rate of productivity growth, but the fact depends critically on a country's level of financial development (in this case measured by Domestic Credit). Their empirical analysis is based on an 83 country data set spanning the years 1960-2000. They also offer a simple monetary growth model in which real exchange rate uncertainty exacerbates the negative investment effects of domestic credit market constraints.

Fourth, Söğüt (2008) investigates the determinants of financial development and private sector credits for a panel of 85 developing and industrial countries using annual data from 1980 to 2006. In this study one of the determinants of financial development, which is inflation, has positive and significant effect on Determinants of Private Sector Credit. Fifth, Boyd et al. (2001) empirically assesses these predictions. The evidence indicates that there is a significant, and economically important, negative relationship between inflation and both banking sector development and equity market activity. Further, the relationship is nonlinear. As inflation rises, the marginal impact of inflation on banking lending activity and stock market development diminishes rapidly. Moreover, we find evidence of thresholds. For economies with inflation rates exceeding 15 percent, there is a discrete drop in financial sector performance, which is measured by Domestic Credit.

Sixth, Gozgor (2014) empirically examines the determinants of domestic credit expansion across a wide range of 24 emerging market economies. He used a dynamic panel data estimation technique to investigate the short-run and long-run effects of internal demand which is lending interest rate and external supply factors, external balance, different measures of trade openness and global uncertainty on 
domestic credit. He found that loose monetary policy in the domestic market, differences between domestic and global lending rates and real trade openness positively and significantly contribute to domestic credit levels. Seventh, Suh (2012) examines the different effects of macro prudential policy and monetary policy on credit and inflation using a simple New Keynesian model with credit. In this model, macro prudential policy is effective in stabilizing credit but has a limited effect on inflation. Monetary policy with an interest rate rule stabilizes inflation, but this rule is 'too blunt' an instrument to stabilize credit or in other word interest rate has a negative and significant effect on Domestic Credit.

Eight, Büyükkarabacak and Valev (2010) argue that household credit growth raises debt levels without much effect on long-term income. Rapid household credit expansions generate vulnerabilities that can precipitate a banking crisis. Enterprise credit expansions can have the same effects but it is tempered by the associated increase in income. Their estimations show that household credit expansions have been a statistically and economically significant predictor of banking crises and in my own opinion it can be vice versa. Ninth, Rose and Spiegel (2009) are using a Multiple Indicator Multiple Cause (MIMIC) model. Their analysis is conducted on a cross-section of 107 countries. Their model tries to study on the effect of crisis on financial policy and financial condition, which are measured by domestic credit, asset price, macroeconomics condition, institution and geography of these countries. The evidence shows that banking crisis has negative and significant effect on financial condition, which is measured by Domestic Credit.

Tenth, Arteta and Hale (2008) argue that, through its effect on aggregate demand and country-risk premia, sovereign debt restructuring can adversely affect the private sector's access to foreign capital markets. Using fixed effect analysis, they estimate that sovereign debt rescheduling episodes are indeed systematically accompanied by a decline in foreign credit to emerging market private firms, both during debt renegotiations and for over two years after the agreements are reached. This decline is large (over 20\%), statistically significant, and robust when they control for a host of fundamentals. Eleventh, Rashid (2011) with bank-level data from 81 developing countries, shows that increased foreign bank presence, in case of his research most all of Islamic banking in his research object is foreign bank, and it is associated with increased reliance on non-deposit based funding, which leads to higher interest rate spreads, less credit to the private sector, and higher volatility in bank loans. Twelfth, Brown (2003) an indication of the level of bank finance used in each country can be obtained by examining the level of domestic credit to GDP. Results indicate that Malaysia, Egypt, Jordan and Kuwait have the highest levels of domestic credit provided by the banking system. It shows that 
existence of Islamic banking in these countries has significant and positive effect on Domestic Credit.

\section{Method}

As discussed above, in this research we use a panel data, we collect the data from the Global Financial Development Database which is published by World Bank and last updated in June 2016, we choose the 1990 as a starting year. In this research we choose United Kingdom, Malaysia, Egypt, Kuwait, Qatar, Bahrain and Indonesia as samples of the study. We take these countries not only because these countries meet all the variables data but also the country has massive development of Islamic finance institution.

The method utilized in this model is panel regression advantage in which the advantage is that it produces a greater degree of freedom. The equation of model regression applied will be as follows:

$$
D C B_{i t}=\alpha+\beta_{1} E X R_{i t}+\beta_{2} I N F_{i t}+\beta_{3} I N T_{i t}+\beta_{4} B C_{i t}+\beta_{5} E I B_{i t}+\beta_{6} D C_{i t}+\varepsilon_{i t}
$$

Where:

DCB : Domestic Credit to Private Sector by Banks

EXR : Exchange Rate

INF : Inflation

INT : Lending Interest Rate

BC : Existence of Banking Crisis

EIB : Existence of Wholesale Islamic Banking

DC : Domestic Credit to Private Sector by Banks (lagged 1)

In order to choose best panel regression model, we have to do Chow Test, Haussmann Test or LM to find which model suitable to the characteristics of the data. Basically these three methods can be selected based on the circumstances of the study. But before we get further by doing panel estimation, we should examine our data by doing instrument test; in this research we conduct a unit root test. Furthermore, in order to make our model is best fit with the reality we should also do an assumption test such as autocorrelation, multicollinearity, and heteroscedasticity.

\section{Results and Discussion}

Result

Table 1 reports the results of the Levin, Lin \& Chu an Unit root test, the individual lag is chosen based on the Schwarz Info Criterion (SIC). The tests 
are conducted with trend and intercept. We examine four variable, exchange rate, inflation, lending interest rate and he dependent variable domestic credit by banks. Except exchange rate variable, Levin, Lin \& Chu agreed that domestic credit, inflation, and lending interest rate variable contain are stationary in the first difference since the level of probability value is less than 0.05 . Conversely, the exchange rate variable are stationary in the second difference, in other words it is noted as $\mathrm{d}$ (exchange rate) since the first difference stationary test cannot reject the hull hypothesis but the second difference can reject the null hypothesis.

Table 1. The Results of Stationarity Test

\begin{tabular}{lll}
\hline Variable & Probability & Stationer at \\
\hline Exchange Rate & 0.0000 & Second Different \\
Inflation & 0.0000 & First Different \\
Interest Rate & 0.0004 & First Different \\
Domestic Credit & 0.0074 & First Different \\
\hline
\end{tabular}

Source: Estimated Result

Having concluded that each of the series is stationary, we don't need to proceed whether there exists a long-run equilibrium between the domestic credit by banks and the market risk determinant variables selected.Therefore, our model is best fit either in short-run or long-run equilibrium.

Based on chow test result, Table 2, that compares the best model whether common effect or fixed effects. If null hypothesis chow test is not rejected, the data can simply be pooled together and OLS employed. If this null is rejected, however, then it is not valid to impose the restriction that the intercepts are the same over the cross sectional units and a panel approach must be employed or fixed effect is employed.

Table 2: The Results of Chow Test

\begin{tabular}{ccrc}
\hline Effects Test & Statistic & d.f. & Prob. \\
\hline Cross-section F & 91.804376 & $(6,133)$ & 0.0000 \\
Cross-section Chi-square & 237.416437 & 6 & 0.0000 \\
\hline
\end{tabular}

Source: Estimated Result

From the Table 2, we know that probability value shows significant value, we can assume that chow test appropriately reject null hypothesis. Therefore, it can be 
assume that fixed effect is better to be used than common effect. Based on hausman test result, Table 3, that compares the best model whether fixed effect or random effects. The null hypothesis is Random Effect and the alternative hypothesis is Fixed Effects. If the value of the probability of cross section Random is greater than significant level then a null hypothesis is accepted. The chosen model for panel data regression is Random Effects. Conversely, if the value of probability of cross section Random is less than significant level then hypothesis is rejected, which means the most appropriate model used is fixed effect model.

From the Table 3, we know that probability value shows significant value, we can assume that hausman test appropriately reject null hypothesis. Therefore, it can be assume that fixed effect is better to be used than random effect. Since our result indicate that the best model is Fixed effect, we don't need to do a Lagrange multiplier (LM) tests because it has been covered by Chow test in choosing whether fixed effect of common effect. After we got our model specification, we have to do a test of assumptions, which are autocorrelation, multicollinearity, and heteroscedasticity test.

Table 3. The Results of Hausman Test

\begin{tabular}{cccc}
\hline Test Summary & Chi-Sq. Statistic & Chi-Sq. d.f. & Prob. \\
\hline Cross-section random & 136.792443 & 5 & 0.0000 \\
\hline
\end{tabular}

Source: Estimated Result

Because our data is an autoregressive model (there is a lag dependent variable that placed as independent variable) Durbin-Watson d statistic may not be used to detect (first order) serial correlation in autoregressive models, because the computed $d$ value in such models generally tends toward 2, which is the value of $d$ expected in a truly random sequence. In other words, if we routinely compute the $d$ statistic for such models, there is a built-in bias against discovering (first order) serial correlation. Despite this, many researchers compute the $d$ value for want of anything better. However, Durbin himself has proposed a large-sample test of firstorder serial correlation in autoregressive model, durbin $h$ test.

But this test is not as powerful in a statistical sense as the Breusch Godfrey (the BG test) test, such as in Table 4. Moreover Durbin h has a weakness, Durbin $\mathrm{h}$ test cannot be used to detect autocorrelation in research with large number of observation. Since our research has large numbers of sample this is why we rather use BG test than Durbin h test. 
Table 4: The Results of Breusch Godfrey (the BG test) test

\begin{tabular}{ccccl}
\hline Variable & Coefficient & Std. Error & t-Statistic & Prob. \\
\hline Resid01(-1) & 0.259558 & 0.104463 & 2.484682 & 0.0147 \\
Resid01(-2) & 0.119163 & 0.108366 & 1.099632 & 0.2742 \\
Resid01(-3) & -0.141342 & 0.123104 & -1.148156 & 0.2538 \\
Resid01(-4) & 0.033575 & 0.121495 & 0.276349 & 0.7829 \\
Resid01(-5) & -0.012600 & 0.103266 & -0.122013 & 0.9031 \\
Resid01(-6) & -0.029101 & 0.094748 & -0.307146 & 0.7594 \\
R-squared & 0.090130 & & & \\
\hline
\end{tabular}

Source: Estimated Result

Based on this result, first we calculate the chi-square value. We can get the chi-square value by multiplying the $\mathrm{n}-\mathrm{p}$ and the R-squared, and then we get 9.28339. After we get the chi-square value, we compare this value with the chisquare table; we know that the chi square value shows 18.547. Since the chi-square test result doesn't exceed the chi-square table, we can conclude that we cannot reject the null hypothesis of no serial correlation and we assume that our model is free from autocorrelation problem.

Table 5: The Summary Results of Auxiliary Regression of Multicolinearity

\begin{tabular}{clc}
\hline Auxiliary & \multicolumn{1}{c}{ Dependent Variabel } & $\mathbf{r}^{\mathbf{2}}$ \\
\hline 1 & D(Exchange_Eate) & 0.680681 \\
2 & Inflation & 0.831686 \\
3 & Lending_Interest_Rate & 0.925649 \\
4 & Existence_of_IB & 0.759304 \\
5 & Banking_Crisis & 0.535756 \\
6 & Domestic_Credit_by_Banks(-1) & 0.917689 \\
7 & Main Regression & 0.978086 \\
\hline
\end{tabular}

Source: Summary of Estimated Rsult

In this research to detect multicollinearity, we are looking at the matrix of correlations between the individual variables or auxiliary regression to detect 
the multicollinearity. The summary of the auxiliary regression is presented in the Table 5. In this research we use Park test to detect heteroscedasticity problem in the model, park formalizes the graphical method by suggesting that $\sigma^{2} \mathrm{i}$ is some function of the explanatory variable Xi. If $\beta$ turns out to be statistically significant, it would suggest that heteroscedasticity is present in the data. If it turns out to be insignificant, we may accept the assumption of homoscedasticity. In this research, we use park test on eviews. The result is as follow:

Table 6: The Results of Park Test

\begin{tabular}{lrrrr}
\hline \multicolumn{1}{c}{ Variable } & Coefficient & Std. Error & t-Statistic & Prob. \\
\hline D(Exchange_Rate) & -0.000149 & 0.000633 & -0.234698 & 0.8149 \\
Inflation & -0.035316 & 0.077313 & -0.456787 & 0.6487 \\
Lending_Interest_Rate & 0.177159 & 0.173473 & 1.021249 & 0.3093 \\
Banking_Crisis & 0.520266 & 1.265730 & 0.411040 & 0.6818 \\
Existence_of_IB & 1.413228 & 1.210789 & 1.167196 & 0.2456 \\
Domestic_Credit_by_Bank(-1) & -0.016647 & 0.019674 & -0.846104 & 0.3993 \\
\hline
\end{tabular}

Source: Estimated Result

From the result in Table 6 , we get that the model is fit the homoskedasticity assumption. It can be seen from the p-value from the Table 6 , because there is no significant value in all independent variables. Since our model is not suffered from autocorrelation, multicolinearity and heteroscedasticity, we can assume that our model is fit in describing the real condition. Then, we are going to interpret our result.

Based on chow test, Haussmann test and LM test, the best model is Fixed Effect. The model is in the following Table 7 . The $t$ ratio aims to determine whether the independent variables used in the model affect the dependent variable. When the prob value is smaller than 0.05 , the independent variables used in the model has partially an effect on the dependent variable. Based on Table 7 we know that only three independent variables that have significant value, these are exchange rate, inflation and domestic credit by banks (previous 1 year ago). It can be concluded that only two independent variables that partially affected the dependent variable. 
Table 7. The Empirical Results

\begin{tabular}{lcccc}
\hline \multicolumn{1}{c}{ Variable } & Coefficient & Std. Error & t-Statistic & Prob. \\
\hline D(Exchange_Rate) & 0.003856 & 0.001512 & 2.549623 & 0.0119 \\
Inflation & -0.420334 & 0.164412 & -2.556581 & 0.0117 \\
Lending_Interest_Rate & -0.068771 & 0.275026 & -0.250052 & 0.8029 \\
Banking_Crisis & -0.446881 & 3.146456 & -0.142027 & 0.8873 \\
Existence_of_IB & 2.366918 & 2.915742 & 0.811772 & 0.4184 \\
Domestic_Credit_by_Bank(-1) & 0.869165 & 0.049579 & 17.53090 & 0.0000 \\
\hline R-squared & 0.970782 & & & \\
Adjusted R-squared & 0.968126 & & & \\
F-statistic & 365.4829 & & & \\
Prob(F-statistic) & 0.000000 & & & \\
\hline
\end{tabular}

Source: Estimated Result

In this regression test we aim to determine whether the independent variables used in the model, affect the dependent variable simultaneously. To see whether there is an effect or not, it can be seen from the value Prob (F-statistic) in the table 7. If the value is smaller than 0.05 , it can be concluded that, at $\alpha$ of 0.05 independent variables affect the dependent variables simultaneously. From the table above it can be seen that, sig F is 0.00 below the value of $\alpha$ is 0.05 . It can be concluded that the independent variables in the model used affect the dependent variables simultaneously/synchronously.

The goodness of fit statistics is calculated to determine how much of the variation of independent variables, $d$ (exchange_rate), inflation, lending_interest_ rate, existence_of_ib, banking_crisis and domestic_credit_by_banks(-1), can explain the dependent variable, domestic_credit_by_bank. Based on Table 7 above, it can be seen in the row R-squared of 0.970782and Adjusted R Squared of 0.968126. Researchers chose the value of Adjusted R Square due to haveing more accurate value than the $\mathrm{R}$ Square. The value show 0.970782 or $97 \%$, it indicated that the independent variables used in the model have the ability to explain the dependent variable $97 \%$ while the remaining $3 \%$ is explained by other variables outside the model. 


\section{Discussion}

From the Table 7, we know that there are 6 variables that are included in the regression. All of them passed the assumption test. These are d(exchange_rate), inflation, lending_interest_rate, existence_of_ib, banking_crisis and domestic_credit_ by_banks(-1). Here we will explain the multiple regression result. I will sort the longer variable name to make it more efficient. The equation that is formed will be explained as follows:
$\mathrm{DCB}=10.66657+0.003856 \mathrm{EXR}-0.420334 \mathrm{INF}-0.068771 \mathrm{INT}-0.446881$ $\mathrm{BC}+2.366918 \mathrm{EIB}+0.869165 \mathrm{DC}$

It means, If EXR, INF, INT, EIB, BC and DC is equal to 0 (zero), the DCB will increase by $13.01197 \%$ of GDP. Exchange Rate (EXR) shows positive and significant value in the result and show coefficient value 0.003856 . It means if INF, INT, EIB, BC and DC are equal to 0 (zero) and EXR increases one point the DCB will increase by $0.3 \%$ of GDP assuming ceteris paribus. We will explain our reasoning from this result. When exchange rate depreciated (the nominal is increase) the price of imported goods will rise so the domestic credit will decrease, as the law of demand, if the price of goods rises, the demand will decrease. This result is supported by Ekinci (2016) he said that exchange rate has a positive effect on return and return volatility respectively, which bank's return came from credit, logically more credit it lends, more return it has. Moreover, Ezeji (2014) wrote that exchange rate doesn't have significant effect on domestic credit based on Granger causality test. Our research show an effect but it is in small portion, it is supported by Magud et.al., (2011) found that exchange rate flexibility may also play a role on credit expansion but in small effect. This research can be a reference for future research since exchange rate effect on credit may present defferent result, either significant or insignificant, This is depended on the research object and the countries studied.

Inflation (INF) shows negative and significant value in the result and show coefficient value: -0.420334 . It means if EXR, INT, EIB, BC and DC are equal to 0 (zero) and INF increases one percent the DCB will decrease by $40 \%$ of GDP assuming ceteris paribus. Our reasoning, if inflation raises central bank will increase the discount rate to stabilize the economy, because of this, commercial banks will raise their interest rate and it will decrease the credit. Our result shows that inflation has negative and significant effect on credit. This result was confirmed by Boyd et.al. (2001), the evidence of their research indicates that there is a significant, and economically important, negative relationship between inflation and financial development that is measured by domestic credit. This result is also supported by Ekinci (2016) that the effect of inflation on bank profitability is negative insignificant. Moreover, Söğüt (2008) found that financial development, in which measured by 
inflation, enhances private sector credit both in the low income countries and high income countries. While exchange rate has unpredictious result, inflation has more predictive result. In others words, future research will have the same result no matter which countries are observed.

INT shows negative and insignificant value in the result and show coefficient value -0.068771 . It means if EXR, INF, EIB, BC and DC are equal to 0 (zero) and INT increases one percent the DCB will decrease by $6 \%$ of GDP assuming ceteris paribus. This study seeks to contribute to the existing literature in several ways. Best of our knowledge, if the bank's interest rate is high, the credit that given to the private sector will be low, because consumer won't like high interest rate on credit. This result is confirmed by Gozgor (2014) the empirical results indicate that lending rate systematically and positively contributes to domestic credit expansion. Moreover Suh (2007) found that the current level of credit depends negatively on the expected future path of the real interest rate and it makes the credit to private sector become lower. Our research best confirms Ezeji's research (2014), he found that the relationship between interest rate and credit showed inverse relation, or it meant that exchange rate had negative and insignificant impact on credit.

In this research, we use banking crisis and existence of Islamic banking as dummy variable. Since these variables are Dummy, we conduct different way to analyze it. First dummy variable is banking crisis, we use this variable to test the proposition that countries will suffer for decreasing more domestic credit while in crisis condition than otherwise. Our results suggest that in condition of banking crisis, countries' domestic credit will decrease for $0.672846 \%$ of GDP than otherwise. To make its more sense, the significance level of this variable shows negative insignificant, we argue that there is an insignificant different in the domestic credit when there is a crisis than otherwise. This result supported by Kwak et.al., (in Rose and Spiegel, 2009) argue that during the boom, many countries experienced dramatic increases in the extension of domestic credit, both for investment and consumption, and the leverage of firms and households exploded. Moreover research by Büyükkarabacak and Neven (2010) wrote that household credit growth has been an important predictor of banking crises. In other word, if the crisis happens the credit will decrease, and vice versa. We suggest that this research supports theory in how Islamic banking more resilience to crisis than conventional bank since the result is insignificant. This research will give implication in developing knowledge since the same research had only been done by IMF.

Second dummy variable is existence of wholesale Islamic banking; we use this variable to test the proposition that countries will earn more domestic credit when Islamic banks exist than otherwise. Our results suggest that when Islamic banks 
are starting their business in the countries, domestic credit from the countries will increase for $1.121858 \%$ of GDP than otherwise. In order to make its more sense, the significance level of this variable shows positively insignificant. We argue that there is an insignificant different in the domestic credit when there is wholesale Islamic banking in the countries than otherwise. Logically, more financial institution in the countries, more domestic credit it has. In order to support this logical order, there is a research done by Brown (2003), he said that the level of bank finance used in each country can be obtained by examining the level of domestic credit to GDP. The more financial institution it has the more domestic credit it has.

In this research we also do an autoregressive model (dependent variable that is placed as independent variable and lagged in period) the result this model, as shown in Table 7 shows that DC shows positive and significant value in the result and show coefficient value: 2.366918. It means if EXR, INF, INT, EIB and BC are equal to 0 (zero) and DC increases one percent the DCB will increase by $203 \%$ of GDP assuming ceteris paribus. It means that today's domestic credit to private sector by banks is influenced by the domestic credit to private sector by banks in past a year ago. Our reasoning from this result is, if consumers feel satisfied with previous credit and they think that they can go with this, they will continue to lend money from banks. This reasoning is supported by our research.

\section{Conclusion}

This paper empirically investigates the determinants of domestic credit across a wide range of 7 countries; these are United Kingdom, Malaysia, Egypt, Kuwait, Qatar, Bahrain and Indonesia, over the period 1990-2014. We use dynamic panel data estimation techniques to examine effects of exchange rate, inflation, lending interest rate, banking crisis and existence of wholesale Islamic banking on domestic credit to private sector by banks. We check the panel model, and the best model to describe determinants of domestic credit to private sector is fixed effect model.

We obtain several notable empirical results. First, the empirical results indicate that lending interest rate, banking crisis negatively and insignificantly contribute to domestic credit to private sector by banks. While the exchange rate and existence of Islamic bank positively and insignificantly contribute to domestic credit to private sector by banks. Inflation negatively and significantly contributes to domestic credit to private sector by banks. Second, the dummy variables, banking crisis and existence of wholesale Islamic banking show insignificant effect on domestic credit to private sector by banks, it means that banking crisis and existence of wholesale Islamic banking gives insignificant difference on domestic credit to private sector 
than otherwise. Third, by doing autoregressive model, we find that today's domestic credit to private sector by banks is depended on domestic credit to private sector by banks a year ago.

Based on experience in this study, the authors have some suggestions that would help for further research. First, it would be nice if next researchers take Economic Value as independent variable, because it is a common component of market risk variable and it will give better result study. Second, next researcher should check whether the data is available in the trusted website or not, because in this research, there is no valid data about existence of wholesale Islamic banking.

Limitation of this study is that there are many data that are categorized as NA or not available. Please make deal with your data first before you decide a variable.

\section{References}

Abduh, M. et.al. (2011). Factor Influence Depositor's Withdrawal Behavior in Islamic Banking: A Theory of Reasoned Action. World Academy of Science, Engineering and Technology, 60: 2074-2079.

Aghion, P. et.al. (2009). Exchange rate volatility and productivity growth:The role of financial development. Journal of Monetary Economics, 56 (4): 494-513.

Arteta, C. \& G. Hale. (2008). Sovereign Debt Crises and Credit to the Private Sector. Journal of International Economics, 74 (1): 53-69.

Askari , H. et.al. (2015). Introduction to Islamic Economics: Theory and Application. Solaris South Tower: Jhon Wiley \& Sons.

Boyd, J. H. et.al. (2001). The Impact of Inflation on Financial Sector Performance. Journal of Monetary Economics, 47: 221-248.

Brown, K. (2003). Islamic Banking Comparative Analysis. The Arab Bank Review, 5(2): 43-50.

Büyükkarabacak, B. \& N.T. Valev. (2010). The role of household and business credit in banking crises. Journal of Banking \& Finance, 34: 1247-1256.

Caballero, R. \& A. Krishnamurthy. (2005). Exchange Rate Volatility and the Credit Channel in Emerging Markets: A Vertical Perspective. International Journal of Central Banking, 1 (1): 207-245.

Ekinci, A. (2016). The Impact of Market Risk on Bank Performance: Evidence from Turkey. International Journal of Economics and Financial Issues, 6(2): 427-434.

Ezeji, C. E. (2014). The Impact of Macro-Economic Indicators on Domestic Credit in Commercial Banks in Nigeria. International Journal of Empirical Finance, 2(1): 34-44. 
Gozgor, G. (2014). Determinants of domestic credit levels in emerging markets: The role of external factors. Emerging Markets Review, 18: 1-18.

IMF. (2016). World Economic Outlook. New York: International Monetary Fund. Jones, G. (2016). Banking Crisis: Perspectives from The New Palgrave Dictionary. Hampshire: Palgrave Macmillan.

Magud, N. E. et.al. (2011) Capital Inflows, Exchange Rate Flexibility, and Credit Booms. NBER Working Paper, 17670: 1-33.

Obstfeld, M. (2012). Does The Current Account Still Matter? NBER Working Paper Series (17877): 1-65.

Pandit, B. (2016). Domestic Credit. Retrieved July 3, 2016, from Busines Pandit: http://www.businesspundit.com/encyclopedia/economics/domestic-credit/

Rashid, H. (2011). Credit to Private Sector, Interest Spread and Volatility in Credit Flows: Do Bank Ownership and Deposits Matter? DESA Working Paper. 105: 1-22.

Rose, A. K. \& M.M. Spiegel. (2009) Cross-Country Causes and Consequences of the 2008 Crisis: Early Warning. Federal Reserve Bank of San Fransisco, 17: 1-55.

Söğüt, E. (2008) The Determinants Of Financial Development And Private Sector Credits: Evidence From Panel Data. (Unpublished Thesis). Turkey: The Graduate School of Social Sciences of Middle East Technical University.

Suh, H. (2012) Dichotomy Between Macroprudential Policy and Monetary Policy on Credit And Inflation. Federal Reserve Bank of Philadelphia Working Paper, 13(6): 1-23.

WEF. (2016). The Global Competitiveness Report 2015-2016. Cologny: World Economic Forum.

World Bank. (2016). World Development Indicator. New york: International Bank for Reconstruction and Development/The World Bank. 